CIRJE-F-318

\title{
Exchange Rate Misalignment: \\ A New Test of Long-Run PPP Based on \\ Cross-Country Data
}

Pan A. Yotopoulos

University of Florence and ( emeritus) Stanford University

Yasuyuki Sawada

University of Tokyo

February 2005

CIRJE Discussion Papers can be downloaded without charge from:

http://www.e.u-tokyo.ac.jp/cirje/research/03research02dp.html

Discussion Papers are a series of manuscripts in their draft form. They are not intended for circulation or distribution except as indicated by the author. For that reason Discussion Papers may not be reproduced or distributed without the written consent of the author. 


\title{
Exchange Rate Misalignment:
}

\section{A New Test of Long-Run PPP Based on Cross-Country Data}

\author{
by \\ Pan A. Yotopoulos \\ University of Florence and \\ (emeritus) Stanford University and \\ Yasuyuki Sawada* \\ University of Tokyo
}

\begin{abstract}
We formulate and implement a new empirical procedure to examine the validity of PPP in the long-run for 153 countries by using the familiar cross-country data set of Heston, Summers, and Aten (2002). Unlike the existing studies that rely on mean reversion of real exchange rates, we explicitly examine country-specificity in the deviations of the nominal exchange rate from PPP. We find, first, that out of a total of 153 countries, 132 countries have achieved PPP within twenty years, 1980-2000 and 105 countries have attained PPP over ten years, 1990-2000. Second, according to the results, our method can be accepted as a workable shortcut of the direct, fullinformation approach of Yotopoulos (1996) that tests for long-run PPP utilizing micro-ICP data. This becomes an important characteristic of this paper since comprehensive micro-ICP data are no longer easily available. As a by-product, of the empirical validation of our shortcut approach, our empirical results are in favor of the Ricardo-Balassa-Samuelson effect.
\end{abstract}

JEL code: F31

Keyword: Purchasing Power Parity; Country Specificity of Exchange Rate Misalignment; Misalignment and Growth; Country-specific Real Exchange Rates; The Ricardo-SamuelsonBalassa Effect

* Corresponding author: Yasuyuki Sawada, Faculty of Economics, University of Tokyo, 73-1 Hongo, Bunkyo-ku, Tokyo 113-0033, Japan. Phone: +81-3-5841-5572. Fax: +81-35841-5521. E-mail: sawada@e.u-tokyo.ac.jp

(C) Copyright 2005 by the authors. All rights reserved. Credit should be given in all cases, although permission from the authors is not necessary for quotations that do not exceed one paragraph in length. 


\section{Introduction}

Since Cassel (1921) and Keynes (1923) opened Pandora's box of real exchange rates, a profusion of related concepts has cropped up in the literature. It is not surprising that the abundance of definitions and standards for the real exchange has become a frequent source of confusion and often leads to contradictory policy advice (Krugman and Taylor, 1978; Edwards, 1989; Yotopoulos, 1996). More recently, the precise specification of the real exchange rate has become even more important in view of the pivotal role that exchange rate misalignment has assumed in explaining the uneven development performance of various countries. It is now widely accepted that chronic misalignment in the real exchange rate has been a major source of slow growth in Africa and Latin America, while prudent macroeconomic, trade and exchange rate policies have fostered growth in Asia (World Bank, 1984; Dollar, 1992; Edwards,1988; and Ghura and Grennes,1993; Rodrik, 1994; Yotopoulos, 1996). This becomes even more crucial in view of a battery of policy interventions that have as their primary objective to restore exchange rate equilibrium.

In designing appropriate exchange rate policies, it becomes quite important to gauge first the speed of exchange rate adjustment in various countries regardless of their exchange rate regimes (Taylor and Taylor, 2004). Moreover, systematic deviations of nominal exchange rates (NER) from their purchasing power parity (PPP) levels may engender serious instabilities of the international macroeconomic system. There exist numerous studies that investigate how well the PPP applies in both the short run and the long run (Taylor and Taylor, 2004; Sarno and Taylor, 2002). While the early literature found that exchange rates over time did not revert to their PPP levels (Taylor, 1988), there is an emerging consensus more recently that PPP holds in the long run (Taylor and Taylor, 2004). This more recent literature, that focuses exclusively on mean reversion of real exchange rates, found that the half-life of PPP deviations appears to be approximately four years, whether using time-series or cross-section data sets (Taylor and Taylor, 2004; Frankel and Rose, 1996). However, an important drawback of these recent studies is that they 
investigate the overall property of real exchange rate movements, totally ignoring countryspecificity. Yotopoulos (1996), on the other hand, expanded the micro-PPP information of the "benchmark countries" of the International Comparisons Project (ICP, Kravis. Heston and Summers, 1992) in order to estimate the real exchange rate (RER) on a country-specific basis That served to test directly for the impact of exchange rate misalignment on development in an endogenous growth model. Misalignment was found to have strongly negative effects on a county's rate of growth.

In this paper we take a different approach to explore the validity of PPP in the long run on a country-specific basis. We formulate a novel empirical procedure to estimate the importance of country specificities in the degree of chronic misalignment in nominal exchange rates, thus by-passing the direct (and more tedious) approach of calculating country-specific RER. The implementation of the new estimation employs the standard set of cross-country data of Heston, Summers, and Aten (2002).

The balance of this paper is organized as follows. In Section 2, we present the theoretical framework for deriving the chronic deviation of the NER from the PPP exchange rate. Section 3 formulates the econometric model for testing the long-run PPP by using the 153-country sample, for two partially overlapping periods. Section 4 presents the results of the empirical implementation. Section 5 examines the validity of our shortcut method of deriving country-specific RER by comparing the results of the micro-PPP approach of the Yotopoulos panel of countries/years with the matching country/year panel using the data of the macro-PPP approach. The conclusions appear in Section 6.

\section{Chronic Misalignments of the Exchange Rate: A Conceptual Framework}

The point of origin of our conceptual framework is the following index of a country's relative (to the U.S., the numeraire country) price level at time $t$ : 


$$
R P L(i, t)=\frac{1}{e(i, t)}\left[\frac{P(i, t)}{P(U S, t)}\right],
$$

where $e$ and $P$ represent a country's nominal exchange rate and overall price level, respectively. Note that the relative price level in equation (1) has been quantified by Summers and Heston (1991), and by Heston, Summers, and Aten (2002). In order to model the nominal exchange rate misalignments, we postulate the following decomposition:

$$
\frac{1}{e(i, t)}=\left[\frac{P_{T}(U S, t)}{P_{T}(i, t)}\right] u(t) \varepsilon(i) w(i, t)
$$

where $P_{T}$ is a price of tradables and the price ratio, $P_{T}(i, t) / P_{T}(U S, t)$, represents the purchasing power parity also in prices of tradables. Note that the misalignment of NER from PPP has been decomposed into an aggregate time-specific component, $u(t)$, a country-specific fixed component, $\varepsilon(i)$, and another time-variant component, $w(i, t)$. The variable $\varepsilon(i)$ represents the degree of the country-specific chronic misalignment of the nominal exchange rate, NER, which can be attributed to systematic factors, such as chronic market imperfections, transaction costs, and/or government intervention in the foreign exchange market in country $i$. In other words, $\varepsilon(i)$ is a long-term deviation of NER from PPP, representing the chronic deviation of NER from PPP. ${ }^{1}$ The time-specific term, $u(t)$, can be interpreted broadly as representing the time-trend of exchange rate parity fluctuations of the U.S. dollar.

Let $P_{N}$ represent the price of nontradables. Combining (1) and (2) with the definition of the price index, $P(i, t)=P_{T}(i, t)^{a(i, t)} P_{N}(i, t)^{1-a(i, t)}$, where $\alpha(i, t)$ denotes the weight of tradable goods, gives a relationship between $\operatorname{RPL}(i, t)$ and the real exchange rate (RER). The latter is defined as the internal terms of trade, or the relative prices of tradables to nontradables: 


$$
R P L(i, t)=\left[R E R(U S, t)^{1-\alpha(U S, t)} u(t)\right] \varepsilon(i) R E R(i, t)^{\alpha(i, t)-1} w(i, t),
$$

where $R E R=P_{T} / P_{N}$. In the equation above we note that the term in brackets is independent of the country $i$.

\section{The Econometric Model}

The econometric model involves the estimation of chronic NER misalignment as measured by $\varepsilon(i)$ in equation (2). It is a plausible assumption that the weight of traded goods is represented by the OPEN index, defined as the share of exports and imports to GDP, $\mathrm{OPEN}=(\mathrm{EX}+\mathrm{IM}) / \mathrm{GDP}$. The data for this index are available in Heston, Summers, and Aten (2002). This positivist definition of tradability as the share of the value of the total trade flow to the total of value-added in a country, will do service in this case since we lack data for a definition of the actual commodities that effectively enter international trade in each country, conditional on a normative component that defines the minimum participation required in order to constitute "effective trade." (Yotopoulos, 1996). The OPEN index is expected to have positive one-to-one correspondence with the share-weight of tradables.

The specification of the RER rests on the Ricardo principle (Ricardo, 1817; Balassa, 1964; Samuelson, 1964) that causally relates the decrease in the relative price of tradables to the level of development. The RER is therefore specified as a function of per capita income. Formally, our assumption leads to:

$$
R E R(i, t)=\beta_{1}(i) \beta_{u}(i, t) R G D P C H(i, t)^{\beta_{2}},
$$

where $R G D P C$ is real per capita GDP and $\beta_{1}$ is a measure of chronic RER misalignments which vary across countries. The other time-variant deviations from

\footnotetext{
${ }^{1}$ Note however that country-specific effects for the numeraire country, the U.S., are not captured.
} 
the equilibrium RER are represented by $\beta_{u}$. Equation (4) represents the RicardoBalasa-Samuelson effect when $\beta_{1} \beta_{2}<0$, under an assumption that $E\left[\beta_{u}\right]=1 .^{2}$ Using equation (4) and rewriting equation (3) by taking the logarithm of both sides, gives a modified determination of relative price levels. Equation (5) will be estimated by using cross-country data:

$$
\begin{aligned}
\ln R P L(i, t)= & {\left[\ln \beta_{1}(i)\right][\operatorname{OPEN}(i, t)-1] } \\
& +\beta_{2}[\operatorname{OPEN}(i, t)-1] \cdot \ln \operatorname{RGDPCH}(i, t)+\eta(i)+\mu(t)+v(i, t),
\end{aligned}
$$

where

(6) $\quad \eta(i)=\ln \varepsilon(i)$,

(7) $\quad v(i, t)=\ln w(i, i)+\ln \beta_{u}(i, t)[\operatorname{OPEN}(i, t)-1]$.

We postulate that the error term $v(i, t)$ in equation (5) obeys an independent process with mean zero. However, considering equation (7), we allow for the possibility of hetereskedasticity in the error term, $v$, above when we estimate equation (5). The estimation uses OLS with the Huber-While's heteroskedasticity robust standard errors.

\section{Empirical Implementation and Estimation Results}

The estimation of equation (5) utilizes the panel data set of international comparisons of the Penn Word Table 6.1, summarized in Heston, Summers, and Aten (2002). The panel for the period 1980-2000 consists of 153 countries. We employ two sample periods, i.e., 1980-2000 and 1990-2000. Numbers of the valid samples are 2839 and 1585 , respectively. The typology of the data, with a large

\footnotetext{
${ }^{2}$ We cannot test this specification because of the lack of data on the real exchange rate defined as the internal terms of trade. Using the explicit estimation of the real exchange rate of 123 country-year observations, Yotopoulos (1996) found a linear version of this RER equation. His result can be interpreted as a special case of equation (4).
} 
number of cross-sectional units (153 countries) and a few periods (10 or 20 years) fits into the framework of the panel-data analysis. Moreover, since the model applies only to the 153 countries in the study (cross-sectional units) and it is not used for extrapolation outside the sample, the observed differences across countries can be treated as parametric shifts of the regression function. It is reasonable, therefore, to employ the fixed effects model to estimate equation (5). More precisely, we will estimate this model as the least squares dummy variable (LSDV) model with time-specific effects.

Tables 1 and 2 summarize our estimation results for the baseline coefficient, $\ln \beta_{1}(i)$ and for $\beta_{2}$, and $\eta(i){ }^{3}$ These estimated coefficients provide supportive evidence for the condition that $\beta_{1} \beta_{2}<0$. Although the estimated $\beta_{2}$ 's are not statistically significant, the directions of the estimated coefficients are consistent with the Ricardo-Balassa-Samuelson effect.

Based on equation (5) we can test the long run PPP by testing whether the estimated country-fixed effects, $\eta(i)$, are different from zero or not. Individual estimates are also reported in Tables 1 and 2. For the results of these tables we employed cross-country data covering 1980-2000 and 1990-2000, respectively, and for 153 countries. Hence, the results in Table 1 relate to testing longer-term PPP over 20 years, while results in Table 2 cover 10 years. Based on the findings of the two tables we fail to reject PPP in 21 countries for 1980-2000, while the corresponding number for 1990-2000 is 48 . These figures indicate that out of 153 countries, 132 countries which comprise about $86 \%$ of all countries, have achieved PPP within 20 years and 105 countries have attained PPP in 10 years, 1990-2000. Our results are consistent with the half-life of PPP deviations of about four years, the emerging consensus in the literature.

\footnotetext{
${ }^{3}$ Results of individual estimates for $\ln \beta_{1}(i)$ are not presented in the Tables but are available from the authors upon request.
} 


\section{Empirical Validation of the Shortcut Method of Deriving Country-Specific RER}

Our empirical strategy for estimating county-specific PPP is open to criticism on two grounds. First, in employing the reduced-from equation (5) it relies heavily on a particular functional form of the Ricardo-Balassa-Samuelson equation (4). Second, it uses the only set of more recent data currently available, the aggregated ICP data from the Penn World Table (Heston, Summers, and Aten, 2002). These data have originated through extrapolation from a small number of countries and years, i.e., from few "benchmark observations," for which micro-PPP data are available, thus generating a potential bias of our estimation results.

In order to investigate the validity of our approach with respect to the data used we compare our results with the Yotopoulos' (1996) results based on microPPP data reported for 80 countries in total (and with annual observations (for at least in one of the years for each country and for most for multiple of the four years) for $1970,1975,1980,1985$, that the ICP survey covered (Kravis, Heston, and Summers 1992). With respect to the methodology of deriving the internal terms of trade, the relative prices of tradables to nontradables for each country, and therefore the PPP country-specificity, the Yotopoulos approach resorted to a full information technique. It consists of using the micro-PPP data of the countries in the panel in order to compute the ratio of each country's prices of tradables to nontradables, normalized by the international prices of the same commodities (the U.S. numerairecountry prices) whether these are in the tradable or nontradable international set (Yotopoulos, 1996: Ch. 6, 108-116). The weights of the relative prices of tradables to nontradables for the implementation of this procedure are derived from countryspecific world trade data and they are normalized by the country's GDP. More specifically for our test, these micro-ICP data yield estimates of the ratio of PPP for tradables and NER, i.e., $P P P_{T} / e$. These data allowed us to estimate the countryspecific deviation from $P P P, \eta(i)$, in equation (6). The procedure employed is to estimate the following logged version of equation (2): 


$$
\ln \left[\frac{P_{T}(U S, t) / P_{T}(U S, t)}{e(i, t)}\right]=\eta(i)+\ln u(t)+\ln w(i, t) .
$$

For the period covering 1975-1985, we have estimated the country-specific deviation from $P P P, \eta(i)$, by using two data sets, i.e., aggregated ICP data (Heston, Summers and 2002) and micro ICP data as above. The results of testing-for longrun PPP are summarized in Table 3. As shown in the Table there exist matching panel data for making this comparison for only 22 cases. Of these, the results obtained by the two different methods diverge in only 5 cases. We consider this as supportive evidence for our reduced-from approach of estimating equation (5). ${ }^{4}$ Since there is a consistency between the two sets of estimates, the method that relies on macro-ICP data can be accepted as a workable short-cut of the full information process that relies on micro-ICP data.

There is another interesting finding that emerges from the comparison of the results in Table 3. In the 22 matching panel-data cases the PPP is unambiguously rejected for both sets of data in 16 cases and accepted in only one, while in the balance of 5 cases the two data sets lead to contradictory results. ${ }^{5}$ On the other hand, in Tables 1 and 2, we fail to reject PPP for a few only countries. This interesting discrepancy may suggest that, in the recent years we have more supportive evidence for PPP, while PPP is rejected for earlier years. This is consistent with the results of other early empirical studies which consistently found for the failure of PPP (Taylor and Taylor, 2004).

\footnotetext{
${ }^{4}$ Yotopoulos and Sawada (1996) also found in different comparisons that the rank correlation coefficients for the cross-country NER distortions from micro- and macro-ICP data are positive and significant.

5 The results are not presented but are available from the authors upon request.
} 


\section{Conclusions}

Unlike the existing studies of mean reversion of real exchange rates, we explicitly take into account the country-specificity in measuring deviations from PPP. First, we found that $60 \%$ and $86 \%$ of all countries have achieved PPP within ten years and over 20 years, respectively, and only $14 \%$ of countries experienced persistent deviation of NER from PPP. Our findings are prima facie consistent with the emerging consensus in the literature that in the more recent past deviations from purchasing power parity (PPP) appear to have half-lives of approximately four years. Moreover, we obtained an additional, new and important finding, that the property of exchange-rate deviations from PPP is basically country-specific.

As another novelty of our study, we developed a short-cut method for estimating deviations of NER from PPP, based on publicly available cross-country aggregate ICP data. In fact, the difficulty of estimating NER deviations has accounted for the wanton use of a number of imperfect substitutes in the literature. Since this is a new method of dealing with exchange rate distortions, the validation of the results becomes important. It is based on comparison of the short-cut estimates in Table 3 with the results obtained by Yotopoulos (1996) who used the full set of micro-ICP data to estimate exchange rate parities and to weigh the effects of exchange rate misalignment in view of the development experience of the sample countries in years 1970-1985. Our results suggest that the economy of estimation has not impaired the validity of the results. Moreover, the impact of exchange rate misalignment, properly defined, on economic development has been, and continues currently to be, deleterious. 


\section{References}

Balassa, Bela (1964), 'Purchasing Power Parity Doctrine: A Reappraisal,' Journal of Political Economy, 72: 584-596.

Cassel, Gustav (1921), The World's Monetary Problems. New York: E.P. Dutton and Co.

Dollar, David (1992), 'Outward-oriented Developing Economies Really Do Grow More Rapidly: Evidence from 95 LDCs, 1976-1985,' Economic Development and Cultural Change, 40:. 523-544.

Edwards, Sebastian (1988). Exchange Rate Misalignment in Developing Countries. , MD: Johns Hopkins University Press.

Ghura, D. and Grennes, T.J. (1993), 'The Real Exchange Rate and Macroeconomic Performance in Sub-Saharan Africa,' Journal of Development Economics. 42: 155174.

Frankel, Jeffrey A. and Andrew K. Rose (1996), "A Panel Project on Purchasing Power Parity: Mean Reversion within and between Countries," Journal of International Economics, 40 (1-2): 209-24

Heston, Alan, Robert Summers and Bettina Aten (2002), Penn World Table Version 6.1. Center for International Comparisons at the University of Pennsylvania (CICUP).

Keynes, J.M.(1923). A Tract for Monetary Reform, New York: Macmillan.

Kravis, Irving B., Alan Heston and Robert Summers (1982), World Product and Income: International Comparisons of Real Gross Product. Baltimore: MD: Johns Hopkins University Press.

Krugman, Paul R. and Lance Taylor (1978), 'Contractionary Effects of Devaluation,' Journal of International Economics, 8: 445-456.

Rodrik, Dani (1994), "King Kong Meets Godzilla: The World Bank and The East Asian Miracle,' in Albert Fishlow, Catherine Gwin, Stephan Haggard, Dani Rodrik, and Robert Wade, eds., Miracle or Design? Lessons from the East Asian Experience,. Washington, D. C., Overseas Development Council, 15-53.

Ricardo, David (1917, reprint 1963), The Principles of Political Economy and Taxation. Homewood, IL: R.D. Irwin (edition 1963).

Samuelson, Paul A. (1964), "Theoretical Notes on Trade Problems," The Review of Economics and Statistics, 40: 145-154. 
Sarno, Lucio and Mark Taylor (2002), "Purchasing Power Parity and the Real Exchange Rate," IMF Staff Papers, 49: 65-105.

Summers, Robert and Alan Heston (1992), 'The Penn World Table (Mark 5): An Expanded Set of International Comparisons, 1950-1988,' Quarterly Journal of Economics, 106: 327-368.

Taylor, Alan M. and Mark P. Taylor (2004), "The Purchasing Power Parity Debate," Journal of Economics Perspectives, 18: 135-158.

Taylor, Mark P. (1988), “An Empirical Examination of Long-Run Purchasing Power Parity Using Cointegration Techniques,” Applied Economics. 20: 1369-81.

World Bank (1984). Toward Sustained Development in Sub-Saharan Africa. Washington DC: The World Bank.

Yotopoulos, Pan A. (1996), Exchange Rate Parity for Trade and Development: Theory, Tests, and Case Studies. Cambridge University Press.

Yotopoulos, Pan A. and Yasuyuki Sawada (1996), "A New Index of Exchange Rate Distortions Based on Purchasing Power Parity Data," mimeo, Stanford University. 
Table 1

Estimated Results for Sample 1, 1980-2000 ${ }^{6}$

\begin{tabular}{|c|c|c|c|}
\hline & Coefficient & $\begin{array}{l}\text { Standard } \\
\text { Error }\end{array}$ & P-value \\
\hline$\beta_{2}$ & -0.002 & $(0.002)$ & $\begin{array}{l}0.227 \\
0.594\end{array}$ \\
\hline $\begin{array}{c}\ln \beta_{1}(i) \\
\text { (baseline) } \\
\eta(i)\end{array}$ & -0.023 & $(0.042)$ & 0.594 \\
\hline American Samoa & 0.310 & $(0.963)$ & 0.748 \\
\hline Andorra & -1.836 & $(0.996)$ & 0.065 \\
\hline Argentina & -0.385 & $(0.989)$ & 0.697 \\
\hline Armenia & 0.534 & $(0.984)$ & 0.588 \\
\hline Australia & 0.086 & $(0.959)$ & 0.928 \\
\hline Austria & -5.402 & $(1.800)$ & 0.003 \\
\hline Azerbaijan & 1.477 & $(1.286)$ & 0.251 \\
\hline Bahamas & 3.228 & $(2.996)$ & 0.281 \\
\hline Bahrain & -1.042 & $(1.024)$ & 0.309 \\
\hline Bangladesh & -1.823 & $(1.044)$ & 0.081 \\
\hline Barbados & -0.235 & $(0.991)$ & 0.813 \\
\hline Belarus & -2.872 & $(1.030)$ & 0.005 \\
\hline Belgium & -1.448 & $(0.979)$ & 0.139 \\
\hline Belize & -1.112 & $(0.952)$ & 0.243 \\
\hline Bolivia & -0.738 & $(0.991)$ & 0.456 \\
\hline Bosnia and Herzegovina & -0.163 & $(0.959)$ & 0.865 \\
\hline Brazil & -0.200 & $(0.973)$ & 0.837 \\
\hline Brunei & 0.313 & $(0.954)$ & 0.743 \\
\hline Bulgaria & -0.042 & $(0.956)$ & 0.965 \\
\hline Cambodia & -0.143 & $(0.967)$ & 0.882 \\
\hline Cameroon & -1.165 & $(1.040)$ & 0.263 \\
\hline Canada & -1.630 & $(1.593)$ & 0.306 \\
\hline Cape Verde & -3.300 & $(2.740)$ & 0.229 \\
\hline Central African Republic & -1.284 & $(1.004)$ & 0.201 \\
\hline Chad & -0.703 & $(0.978)$ & 0.472 \\
\hline Channel Islands & 0.307 & $(2.021)$ & 0.879 \\
\hline Chile & -0.067 & $(1.457)$ & 0.963 \\
\hline China & -0.578 & $(1.064)$ & 0.587 \\
\hline Colombia & -0.903 & $(0.990)$ & 0.362 \\
\hline Comoros & -0.848 & $(1.208)$ & 0.483 \\
\hline Congo, Dem. Rep. & 1.447 & $(1.200)$ & 0.228 \\
\hline Congo, Republic of & 0.110 & $(1.010)$ & 0.914 \\
\hline Costa Rica & -0.471 & $(1.002)$ & 0.638 \\
\hline
\end{tabular}

${ }^{6}$ Note: Regression with the Huber-While robust standard errors. Results of individual estimates for $\ln \beta_{1}(i)$ are not presented but are available from the authors upon request. The sample size is 2839 and $\mathrm{R}^{2}=0.938$ 
Table 1 (continued)

Estimated Results for Sample 1, 1980-2000

\begin{tabular}{lrrc}
\hline & Coefficient. & $\begin{array}{c}\text { Standard } \\
\text { Error }\end{array}$ & P-value \\
& & & \\
Croatia & & & \\
Cuba & 0.267 & $(0.969)$ & 0.783 \\
Czech Republic & -0.209 & $(0.949)$ & 0.826 \\
Denmark & -0.223 & $(0.956)$ & 0.816 \\
Djibouti & 1.607 & $(3.202)$ & 0.616 \\
Dominica & -0.495 & $(1.497)$ & 0.741 \\
Dominican Republic & -0.491 & $(1.048)$ & 0.639 \\
Ecuador & -1.029 & $(1.114)$ & 0.355 \\
El Salvador & -0.192 & $(1.071)$ & 0.857 \\
Equatorial Guinea & -1.105 & $(1.107)$ & 0.318 \\
Eritrea & -0.437 & $(1.012)$ & 0.666 \\
Estonia & -0.113 & $(1.286)$ & 0.930 \\
Ethiopia & -2.824 & $(3.037)$ & 0.353 \\
Faeroe Islands & 0.045 & $(0.952)$ & 0.963 \\
France & -0.657 & $(2.260)$ & 0.771 \\
French Polynesia & 0.126 & $(0.959)$ & 0.895 \\
Gabon & 1.328 & $(3.614)$ & 0.713 \\
Gambia & 2.041 & $(2.560)$ & 0.425 \\
Georgia & -2.335 & $(3.984)$ & 0.558 \\
Germany & 0.028 & $(1.223)$ & 0.982 \\
Ghana & -0.804 & $(1.067)$ & 0.452 \\
Greece & -0.933 & $(0.957)$ & 0.330 \\
Greenland & -0.689 & $(0.967)$ & 0.476 \\
Grenada & 0.337 & $(1.037)$ & 0.745 \\
Guam & -0.879 & $(0.992)$ & 0.376 \\
Guinea & 0.187 & $(0.957)$ & 0.845 \\
Guyana & -1.116 & $(0.976)$ & 0.253 \\
Haiti & -1.012 & $(0.970)$ & 0.297 \\
Honduras & -0.167 & $(0.960)$ & 0.862 \\
Hong Kong & -0.146 & $(0.964)$ & 0.880 \\
Hungary & 0.379 & $(0.932)$ & 0.684 \\
Iceland & -2.532 & $(1.054)$ & 0.016 \\
India & -0.207 & $(0.998)$ & 0.836 \\
Iran & -1.234 & $(2.176)$ & 0.571 \\
Iraq & -0.297 & $(0.998)$ & 0.766 \\
Ireland & -2.275 & $(1.167)$ & 0.051 \\
Israel & -0.237 & $(1.091)$ & 0.828 \\
Italy & -0.137 & $(3.874)$ & 0.972 \\
\hline & & & \\
& 4.463 & $(5.077)$ & 0.379 \\
\hline
\end{tabular}


Table 1 (continued)

Estimated Results for Sample 1, 1980-2000

\begin{tabular}{lrrr}
\hline & Coefficient. & $\begin{array}{c}\text { Standard } \\
\text { Error }\end{array}$ & P-value \\
& & & \\
Jamaica & & \\
Japan & -1.497 & $(1.750)$ & 0.392 \\
Jordan & 0.211 & $(0.956)$ & 0.825 \\
Kazakhstan & -0.109 & $(0.953)$ & 0.909 \\
Kenya & -2.260 & $(2.114)$ & 0.285 \\
Kiribati & -2.626 & $(2.193)$ & 0.231 \\
Korea, Dem. Rep. & 0.981 & $(1.184)$ & 0.408 \\
Korea, Republic of & 4.202 & $(5.337)$ & 0.431 \\
Kyrgyzstan & -1.820 & $(0.957)$ & 0.057 \\
Laos & -0.272 & $(1.023)$ & 0.790 \\
Lesotho & -0.564 & $(0.987)$ & 0.568 \\
Liechtenstein & -0.291 & $(1.305)$ & 0.824 \\
Luxembourg & 0.092 & $(0.983)$ & 0.925 \\
Macao & -1.611 & $(0.991)$ & 0.104 \\
Macedonia & -1.113 & $(1.010)$ & 0.271 \\
Madagascar & -2.811 & $(1.208)$ & 0.020 \\
Malawi & -4.667 & $(5.550)$ & 0.400 \\
Malaysia & -0.181 & $(0.964)$ & 0.851 \\
Maldives & 0.864 & $(0.948)$ & 0.362 \\
Malta & -1.219 & $(1.100)$ & 0.268 \\
Marshall Islands & -1.857 & $(0.962)$ & 0.054 \\
Mauritius & -1.234 & $(1.002)$ & 0.218 \\
Mexico & -0.724 & $(0.970)$ & 0.456 \\
Micronesia, Fed. Sts. & -0.578 & $(0.970)$ & 0.551 \\
Moldova & -0.876 & $(1.208)$ & 0.468 \\
Mozambique & 0.775 & $(1.070)$ & 0.469 \\
Myanmar & -1.236 & $(1.282)$ & 0.335 \\
Namibia & -0.159 & $(0.953)$ & 0.867 \\
Nepal & -0.847 & $(0.954)$ & 0.374 \\
Netherlands & -3.039 & $(1.138)$ & 0.008 \\
New Caledonia & -0.017 & $(0.953)$ & 0.985 \\
Nicaragua & -0.235 & $(0.961)$ & 0.807 \\
Niger & -1.150 & $(1.042)$ & 0.270 \\
Nigeria & -2.827 & $(1.031)$ & 0.006 \\
Northern Mariana Islands & -0.965 & $(0.950)$ & 0.310 \\
Norway & -2.407 & $(1.095)$ & 0.028 \\
Oman & -1.971 & $(4.031)$ & 0.625 \\
& -1.590 & $(0.984)$ & 0.106 \\
\hline
\end{tabular}


Table 1 (continued)

Estimated Results for Sample 1, 1980-2000

\begin{tabular}{|c|c|c|c|}
\hline$\eta(i)$ & Coefficient. & $\begin{array}{l}\text { Standard } \\
\text { Error }\end{array}$ & P-value \\
\hline Pakistan & -0.583 & $(1.721)$ & 0.735 \\
\hline Panama & -2.040 & $(1.028)$ & 0.047 \\
\hline Papua New Guinea & 0.049 & $(0.955)$ & 0.959 \\
\hline Paraguay & -1.212 & $(1.170)$ & 0.300 \\
\hline Peru & -2.088 & (1.005) & 0.038 \\
\hline Poland & -0.798 & $(0.954)$ & 0.403 \\
\hline Portugal & -0.691 & $(0.956)$ & 0.470 \\
\hline Romania & -1.325 & $(1.027)$ & 0.197 \\
\hline Russia & -0.054 & $(0.981)$ & 0.956 \\
\hline San Marino & -0.091 & $(0.974)$ & 0.925 \\
\hline Sao Tome and Principe & -5.106 & $(1.082)$ & 0.000 \\
\hline Saudi Arabia & -0.417 & $(0.978)$ & 0.670 \\
\hline Sierra Leone & -1.897 & $(2.459)$ & 0.440 \\
\hline Singapore & 3.354 & $(2.597)$ & 0.197 \\
\hline Slovenia & -0.572 & $(0.985)$ & 0.562 \\
\hline Solomon Islands & -1.457 & $(0.980)$ & 0.137 \\
\hline Spain & -1.237 & $(0.964)$ & 0.200 \\
\hline St. Kitts \& Nevis & -0.673 & $(0.956)$ & 0.482 \\
\hline St. Lucia & 0.350 & $(0.948)$ & 0.712 \\
\hline St.Vincent \& Grenadines & 0.303 & (1.929) & 0.875 \\
\hline Sudan & -2.015 & (1.208) & 0.096 \\
\hline Suriname & 0.498 & $(0.951)$ & 0.601 \\
\hline Swaziland & -0.660 & $(1.283)$ & 0.607 \\
\hline Sweden & -1.489 & (1.018) & 0.144 \\
\hline Switzerland & -0.945 & $(1.125)$ & 0.401 \\
\hline Syria & -1.171 & $(0.990)$ & 0.237 \\
\hline Taiwan & -3.095 & (1.698) & 0.068 \\
\hline Thailand & 0.087 & $(0.961)$ & 0.928 \\
\hline Togo & -3.576 & (1.359) & 0.009 \\
\hline Tonga & -0.540 & $(0.983)$ & 0.583 \\
\hline Trinidad \&Tobago & -2.037 & (1.174) & 0.083 \\
\hline Tunisia & 1.507 & $(1.530)$ & 0.324 \\
\hline Turkey & -0.632 & (1.093) & 0.563 \\
\hline Turkmenistan & -7.014 & $(3.741)$ & 0.061 \\
\hline
\end{tabular}


Table 1 (continued)

Estimated Results for Sample 1, 1980-2000

\begin{tabular}{lrrr}
\hline \multicolumn{1}{c}{$\eta(i)$} & Coefficient. & $\begin{array}{c}\text { Standard } \\
\text { Error }\end{array}$ & P-value \\
& & & \\
USA & -1.211 & $(1.026)$ & 0.238 \\
Uganda & -6.723 & $(0.959)$ & 0.000 \\
Ukraine & -49.799 & $(2.007)$ & 0.000 \\
United Arab Emirates & 0.123 & $(0.954)$ & 0.897 \\
United Kingdom & -1.030 & $(1.026)$ & 0.315 \\
Uzbekistan & -2.751 & $(1.744)$ & 0.115 \\
Virgin Islands (U.S.) & -2.066 & $(4.283)$ & 0.630 \\
Yemen & -1.160 & $(1.091)$ & 0.288 \\
Yugoslavia & -0.326 & $(1.151)$ & 0.777 \\
Zambia & 0.275 & $(0.972)$ & 0.777 \\
Zimbabwe & 1.236 & $(1.005)$ & 0.219 \\
\hline
\end{tabular}




\section{Table $2^{7}$}

Estimated Results for Sample 2, 1990-2000

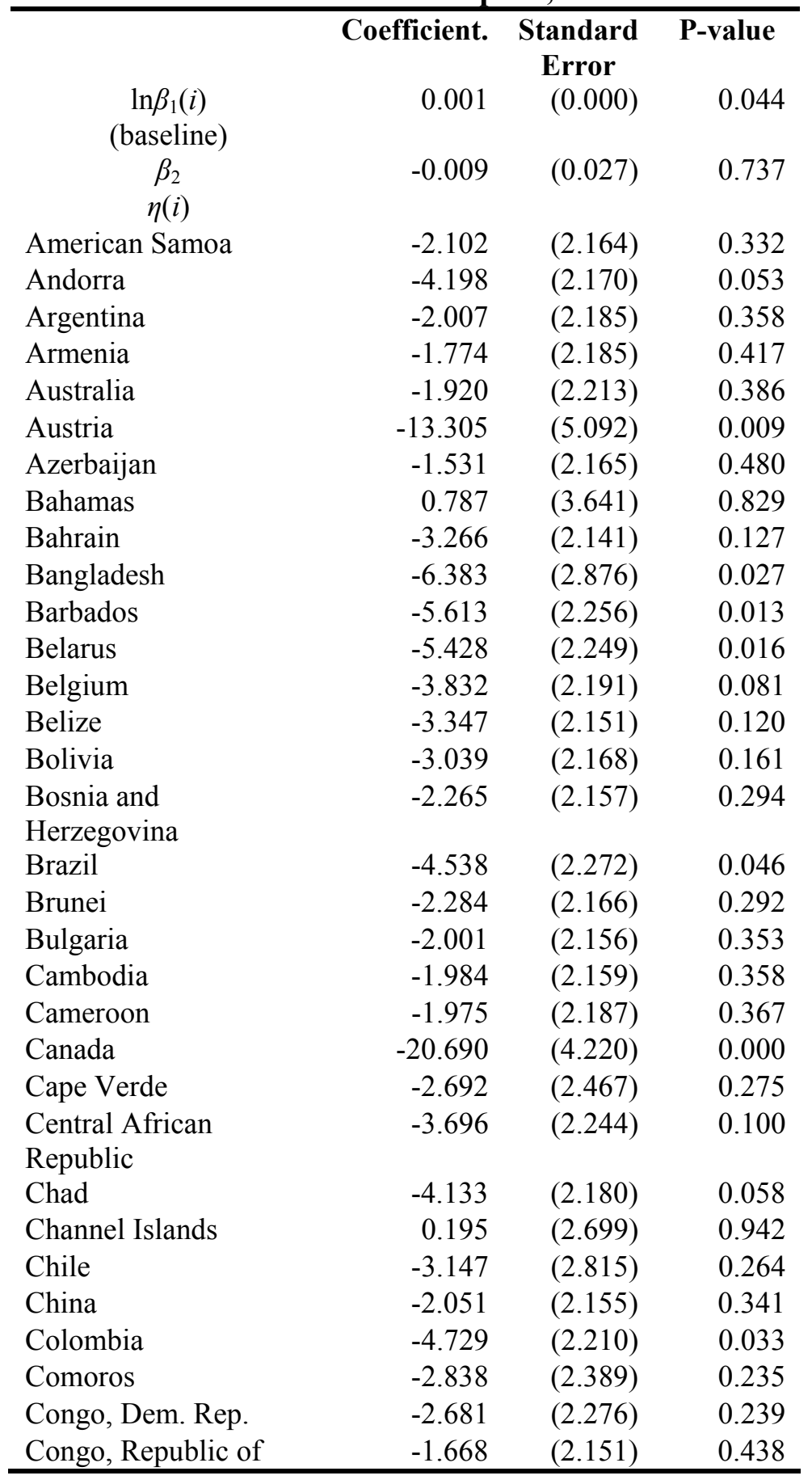

${ }^{7}$ Note: Regression with the Huber-While robust standard errors. Results of individual estimates for $\ln \beta_{1}(i)$ are not presented but are available from the authors upon request. The sample size is 1839 and $\mathrm{R}^{2}=0.948$ 
Table 2 (continued)

Estimated Results for Sample 2, 1990-2000

\begin{tabular}{lrcc}
\hline \multicolumn{1}{c}{$\eta(i)$} & Coefficient. & $\begin{array}{c}\text { Standard } \\
\text { Error }\end{array}$ & P-value \\
& & & \\
Costa Rica & & & \\
Croatia & -3.056 & $(2.212)$ & 0.167 \\
Cuba & -1.822 & $(2.167)$ & 0.401 \\
Czech Republic & -2.431 & $(2.150)$ & 0.259 \\
Denmark & -2.200 & $(2.149)$ & 0.306 \\
Djibouti & 1.411 & $(3.982)$ & 0.723 \\
Dominica & -1.705 & $(2.904)$ & 0.557 \\
Dominican Republic & -6.053 & $(3.314)$ & 0.068 \\
Ecuador & -7.611 & $(2.418)$ & 0.002 \\
El Salvador & 0.720 & $(4.523)$ & 0.873 \\
Equatorial Guinea & -9.028 & $(3.002)$ & 0.003 \\
Eritrea & -2.697 & $(2.180)$ & 0.216 \\
Estonia & -1.862 & $(2.293)$ & 0.417 \\
Ethiopia & -6.725 & $(4.344)$ & 0.122 \\
Faeroe Islands & -2.788 & $(2.173)$ & 0.200 \\
France & -7.372 & $(3.950)$ & 0.062 \\
French Polynesia & -1.916 & $(2.150)$ & 0.373 \\
Gabon & -6.597 & $(7.117)$ & 0.354 \\
Gambia & -0.309 & $(3.339)$ & 0.926 \\
Georgia & -8.768 & $(4.572)$ & 0.055 \\
Germany & -2.362 & $(2.270)$ & 0.298 \\
Ghana & -3.865 & $(2.147)$ & 0.072 \\
Greece & -3.081 & $(2.157)$ & 0.153 \\
Greenland & -3.469 & $(2.157)$ & 0.108 \\
Grenada & -2.500 & $(2.174)$ & 0.250 \\
Guam & -2.122 & $(2.194)$ & 0.334 \\
Guinea & -1.848 & $(2.155)$ & 0.391 \\
Guyana & -4.536 & $(2.218)$ & 0.041 \\
Haiti & -3.393 & $(2.174)$ & 0.119 \\
Honduras & -2.441 & $(2.199)$ & 0.267 \\
Hong Kong & -2.560 & $(2.176)$ & 0.240 \\
Hungary & -1.865 & $(2.145)$ & 0.385 \\
Iceland & -4.726 & $(2.174)$ & 0.030 \\
India & -2.174 & $(2.154)$ & 0.313 \\
Iran & -1.603 & $(3.095)$ & 0.605 \\
Iraq & -3.450 & $(2.218)$ & 0.120 \\
Ireland & -5.078 & $(2.421)$ & 0.036 \\
Israel & $(2.163)$ & 0.499 \\
Italy & $(2.617)$ & 0.199 \\
\hline & $(7.555)$ & 0.850 \\
\hline
\end{tabular}


Table 2 (continued)

Estimated Results for Sample 2, 1990-2000

\begin{tabular}{|c|c|c|c|}
\hline$\eta(i)$ & Coefficient. & $\begin{array}{l}\text { Standard } \\
\text { Error }\end{array}$ & P-value \\
\hline Jamaica & -11.737 & (3.174) & 0.000 \\
\hline Japan & -1.941 & (2.159) & 0.369 \\
\hline Jordan & -2.069 & $(2.145)$ & 0.335 \\
\hline Kazakhstan & -4.662 & (2.244) & 0.038 \\
\hline Kenya & -4.775 & (3.083) & 0.122 \\
\hline Kiribati & -1.167 & $(2.371)$ & 0.623 \\
\hline Korea, Dem. Rep. & 2.309 & $(5.996)$ & 0.700 \\
\hline Korea, Republic of & -4.068 & $(2.178)$ & 0.062 \\
\hline Kyrgyzstan & -1.785 & $(2.143)$ & 0.405 \\
\hline Laos & -2.063 & $(2.185)$ & 0.345 \\
\hline Lesotho & -2.409 & $(2.367)$ & 0.309 \\
\hline Liechtenstein & -1.328 & $(2.146)$ & 0.536 \\
\hline Luxembourg & -3.635 & $(2.166)$ & 0.094 \\
\hline Macao & -2.908 & (2.160) & 0.178 \\
\hline Macedonia & -5.148 & $(2.315)$ & 0.026 \\
\hline Madagascar & -10.471 & $(7.235)$ & 0.148 \\
\hline Malawi & -2.425 & $(2.150)$ & 0.259 \\
\hline Malaysia & -1.572 & $(2.140)$ & 0.463 \\
\hline Maldives & -2.339 & $(2.256)$ & 0.300 \\
\hline Malta & -4.068 & $(2.151)$ & 0.059 \\
\hline Marshall Islands & -3.087 & (2.197) & 0.160 \\
\hline Mauritius & -2.352 & $(2.177)$ & 0.280 \\
\hline Mexico & -2.775 & $(2.168)$ & 0.201 \\
\hline Micronesia, Fed. Sts. & -6.387 & (3.779) & 0.091 \\
\hline Moldova & -1.280 & (2.099) & 0.542 \\
\hline Mozambique & -3.158 & $(2.313)$ & 0.172 \\
\hline Myanmar & -2.460 & $(2.162)$ & 0.255 \\
\hline Namibia & -2.680 & (2.191) & 0.222 \\
\hline Nepal & -5.551 & (2.357) & 0.019 \\
\hline Netherlands & -2.555 & $(2.181)$ & 0.242 \\
\hline New Caledonia & -2.357 & (2.174) & 0.279 \\
\hline Nicaragua & -2.544 & $(2.409)$ & 0.291 \\
\hline Niger & -2.138 & (3.844) & 0.578 \\
\hline Nigeria & -3.257 & $(2.145)$ & 0.129 \\
\hline $\begin{array}{l}\text { Northern Mariana } \\
\text { Islands }\end{array}$ & -4.685 & $(2.244)$ & 0.037 \\
\hline Norway & -1.141 & (3.652) & 0.755 \\
\hline Oman & -3.945 & $(2.186)$ & 0.071 \\
\hline
\end{tabular}


Table 2 (continued)

Estimated Results for Sample 2, 1990-2000

\begin{tabular}{|c|c|c|c|}
\hline$\eta(i)$ & Coefficient & $\begin{array}{l}\text { Standard } \\
\text { Error }\end{array}$ & P-value \\
\hline Pakistan & -0.335 & $(3.880)$ & 0.931 \\
\hline Panama & -3.815 & $(2.176)$ & 0.080 \\
\hline Papua New Guinea & -1.756 & $(2.283)$ & 0.442 \\
\hline Paraguay & -2.173 & $(2.215)$ & 0.327 \\
\hline Peru & -4.963 & $(2.244)$ & 0.027 \\
\hline Poland & -3.175 & $(2.150)$ & 0.140 \\
\hline Portugal & -3.642 & $(2.200)$ & 0.098 \\
\hline Puerto Rico & -2.382 & $(2.176)$ & 0.274 \\
\hline Romania & -2.508 & $(2.233)$ & 0.261 \\
\hline Russia & -2.830 & $(2.165)$ & 0.191 \\
\hline San Marino & -3.074 & $(2.186)$ & 0.160 \\
\hline Sao Tome and Principe & -7.496 & $(2.231)$ & 0.001 \\
\hline Saudi Arabia & -2.799 & $(2.178)$ & 0.199 \\
\hline Sierra Leone & -12.777 & $(2.696)$ & 0.000 \\
\hline Singapore & 25.708 & $(11.501)$ & 0.026 \\
\hline Slovenia & -4.186 & $(2.774)$ & 0.132 \\
\hline Solomon Islands & -3.981 & $(2.180)$ & 0.068 \\
\hline Spain & -3.687 & (2.144) & 0.086 \\
\hline St. Kitts \& Nevis & -2.879 & $(2.156)$ & 0.182 \\
\hline St. Lucia & -1.933 & $(2.157)$ & 0.370 \\
\hline St.Vincent \& & -1.466 & (2.599) & 0.573 \\
\hline \multicolumn{4}{|l|}{ Grenadines } \\
\hline Sudan & -3.830 & $(2.355)$ & 0.104 \\
\hline Suriname & -1.796 & $(2.161)$ & 0.406 \\
\hline Swaziland & -35.333 & $(6.750)$ & 0.000 \\
\hline Sweden & -4.796 & $(2.206)$ & 0.030 \\
\hline Switzerland & -4.619 & $(2.222)$ & 0.038 \\
\hline Syria & -2.984 & $(2.162)$ & 0.168 \\
\hline Taiwan & -5.249 & (2.559) & 0.040 \\
\hline Thailand & -2.062 & $(2.158)$ & 0.339 \\
\hline Tonga & -2.145 & (2.189) & 0.327 \\
\hline Trinidad \& Tobago & -3.327 & $(2.721)$ & 0.222 \\
\hline Tunisia & 0.305 & (2.533) & 0.904 \\
\hline Turkey & -3.443 & $(2.210)$ & 0.120 \\
\hline Turkmenistan & -12.374 & (3.684) & 0.001 \\
\hline USA & -3.507 & $(2.210)$ & 0.113 \\
\hline Uganda & -8.820 & $(2.186)$ & 0.000 \\
\hline
\end{tabular}


Table 2 (continued)

Estimated Results for Sample 2, 1990-2000

\begin{tabular}{lrrr}
\hline \multicolumn{1}{c}{$\eta(i)$} & Coefficient. & $\begin{array}{c}\text { Standard } \\
\text { Error }\end{array}$ & P-value \\
Ukraine & & & \\
United Arab Emirates & -52.270 & $(2.858)$ & 0.000 \\
United Kingdom & -2.658 & $(2.154)$ & 0.218 \\
Uzbekistan & -5.018 & $(2.219)$ & 0.024 \\
Virgin Islands (U.S.) & -3.748 & $(2.260)$ & 0.098 \\
Yemen & -4.336 & $(5.100)$ & 0.395 \\
Yugoslavia & -2.046 & $(2.216)$ & 0.356 \\
Zambia & -2.527 & $(2.224)$ & 0.256 \\
Zimbabwe & -1.979 & $(2.449)$ & 0.419 \\
\hline
\end{tabular}


Table 3

Comparing Macro-ICP Data with Micro-ICP data:

Is Long-Run PPP Rejected for 1975-1985?

\begin{tabular}{|c|c|c|}
\hline & $\begin{array}{c}\text { Test of Long-run PPP } \\
\text { Based on the Macro ICP } \\
\text { (Penn World Table) Data }\end{array}$ & $\begin{array}{c}\text { Test of Long-run PPP Based } \\
\text { on Micro ICP Data } \\
\text { Compiled by Yotopoulos } \\
(1996)\end{array}$ \\
\hline Australia & YES & YES \\
\hline Austria & YES & YES \\
\hline Belgium & YES & YES \\
\hline Canada & YES & YES \\
\hline Colombia & YES & YES \\
\hline Costa Rica & YES & NO \\
\hline France & YES & YES \\
\hline Germany & YES & YES \\
\hline Greece & YES & YES \\
\hline Hungary & YES & YES \\
\hline India & NO & YES \\
\hline Ireland & YES & YES \\
\hline Italy & YES & YES \\
\hline Jamaica & YES & YES \\
\hline Japan & YES & $\mathrm{NO}$ \\
\hline Netherlands & YES & YES \\
\hline Norway & NO & $\mathrm{NO}$ \\
\hline Portugal & YES & YES \\
\hline Spain & YES & YES \\
\hline Sweden & YES & $\mathrm{NO}$ \\
\hline United Kingdom & YES & YES \\
\hline Yugoslavia & NO & YES \\
\hline
\end{tabular}

Note: Results of individual estimates are not presented but are available from the authors upon request. 